of constant quantity, a closed metallic circuit of which travelling motors at all times form a part without ever being short-circuited, or having the current supply cut off from them, and the regulation of the power developed by the motor and absorbed by it without interrupting the continuity of the circuit. An insulated cable connected to one terminal of the generator traverses the whole length of the line, and is interrupted at distances of 20 feet, the divided ends being connected with the opposite faces of a "spring jack," which is at the same time the automatic switch and contact point. The current collector, which is the same length as and carried by the car, is constructed so as to pass between the faces of the "spring jack," and conduct the current to the motor without at any time short-circuiting it or interrupting the main circuit. In series running, there is little danger of damage to the motor by careless driving, or reversing while running ; in descending a gradient there is positive advantage in checking the speed of the car by altering the field connections, so that the armature tends to revolve in the opposite direction to that in which the car is travelling; the power that would otherwise be lost in braking is thus added to that produced by the generator.

Telephonic communication between London and Paris, by Mr. W. H. Preece, F.K.S. The difficulty of such a communication was not the distance, 275 miles, between the two towns, as in the United States speech is maintained between New York and Boston, $35^{\circ}$ miles apart; but the insertion of underground wires at each end, and of a cable in the middle, places difficulties in the way that have to be surmounted. The author has experimented on the cables between Dover and Calais and others, and finds the conditions to be fulfilled simple. The circuit must be metallic, the material copper, and the product of the resistance of the line and its capacity must not exceed 7500 for very good, 5000 for excellent, and 2500 for perfect speech. A circuit approaching as nearly as possible one between London and Paris was made on an artificial cable, and found to comply with the requirements.

On the purification of sewage and water contaminated with organic matter by electrolysis, by Mr. W. Webster. The paper was divided into four sections, of which the fourth referred to the use of the electric current. The fact that water and the salts contained therein are easily decomposed if the current is of sufficient intensity is the explanation of the whole system. The changes taking place in sewage when electrolyzed depend chiefly on the splitting up into their constituent parts of sodium, magnesium, and other chlorides, nascent chlorine and oxygen being set free at the positive and the bases at the negative pole.

The strength of alloys at different temperatures by Prof. W. C. Unwin, F.R.S. In 1877 , the Admiralty made some experiments as to the effect of variation of temperature on the tenacity of copper, Muntz metal, and phosphor bronze, and found that up to $500^{\circ} \mathrm{F}$. the tenacity diminished proportionately with increase of temperature ; in the case of gun metal, on the other hand, the tenacity diminished regularly up to $300^{\circ}$ to $350^{\circ}$, but beyond this temperature there was a sudden reduction in the strength, which was found to be as low as half that at ordinary atmospheric temperature, whilst at $500^{\circ}$ it became nil: the gun metal tested consisted of alloys of copper, tin, and zinc combined in different proportions. The author determined to make a series of experiments, the results of which he brought before the Association. The various alloys used, which are tabulated below, were heated in an oil bath, the temperatures employed, being all below that of the boiling of mercury, were read by means of a mercury thermometer. The results were plotted on a diagram, and given in tables, and show that the decrease of tenacity follows a regular law in each case ; the temperature was given in degrees Fahrenheit, and the tenacity in tons on the square inch.

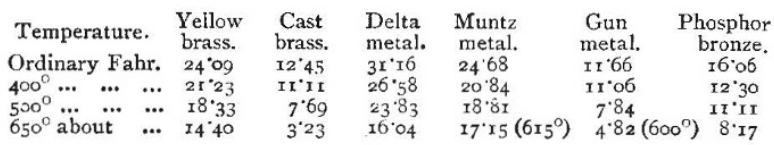

The influence of variation of temperature on the ductility of the same alloys was also experimented on, and was found to vary with the different alloys; with brass and gun metal there was little elongation before fracture ; with Muntz metal it was considerable. In these cases the ultimate elongation diminished with increase of temperature, but in the case of Delta metal it increased. These experiments are of a very important character, and were carried out by the author on account of the very high pressures, and therefore temperatures, at which modern steamengines are worked.

Central station heating and power supply, by $\mathrm{Mr}$. W. W. Phipson. The system consists in the constant circulation of water at high temperature and pressure (viz. $400^{\circ} \mathrm{F}$. and 250 pounds per square inch) from boilers at the supply station, through supply mains covered with non-conducting material, and back to the boilers by means of return mains, the circulation being maintained by pumps. Service boxes to supply the houses are fixed under the footpaths, which are connected to the mains by an inch pipe. From these boxes the house supply is taken by means of copper pipes. A vessel, called a converter, is fixed inside the house, whose use is to permit the water to resolve itself into steam, the pressure of which is controlled by means of a reducing-valve fixed on the copper pipe, before it enters the converter. From this converter the house services are taken. If a supply of both heat and power is required, double or compound converters are used with two reducing-valves, the power being taken from one and the heat from the other.

A curve ranger, by Mr. Alex. P. Trotter. The instrument is an application of the twenty-first proposition of the third book of Euclid, viz. the angles in the same segment of a circle are equal. A half-silvered mirror, such as is used in sextants, is mounted on an axis at one end of a bar, the other being provided with a sight. The motion of the mirror on its axis allows its inclination to the sight to be adjusted. To set out a curve, a pole is set up at each extremity, and the mirror is suitably adjusted. When the poles are seen, the one direct through the unsilvered part and the other by reflection in the silvered part of the mirror in apparent coincidence, and in the middle of the field as shown by the vertical line engraved on the mirror, the instrument is then at the point on the curve required. The mirror being clamped in position, the observer walks in the direction of the curve, and at suitable intervals places himself so that the poles at the extremities of the curve are seen in apparent coincidence.

On the application of the transporting power of water to the deepening and improvement of rivers, by $\mathrm{Mr}$. W. H. Wheeler, M.Inst.C.E. The object of the paper is to show that the transporting power of water may be applied to the proposed purpose, and that under favourable conditions this can be accomplished by breaking up shoals, or the natural bed of a river, by mechanical agency and by mixing the material with the water, and allowing it to be carried away to the sea or estuary in suspension. The author has designed an improved apparatus, which, whilst disintegrating the shoal, mixes its material with the water, allowing it to be effectively transported by the ebb current clear of the channel to be improved.

\section{THE ANTHROPOLOGICAL PAPERS AT THE BRITISH ASSOCIATION:}

THE work of the Section commenced on Thursday, September I.2, by Mr. Francis Galton, F.R.S., reading a paper on the advisability of assigning marks for bodily efficiency in the examinations of candidates for the public services. In the recent report of H.M. Civil Service Commissioners, they state that, a scheme of competition for physical qualifications having been brought before the notice of the War Office, it was not accepted, on the ground that the authorities were " completely satisfied with the physique of the young men who came to them through our examinations." The marks, as at present, of the candidates whose places lie near the dividing line between success and failure, run pretty evenly; therefore it is contended that the State would obtain better servants if such moderate marks were allowed for physical qualifications as to insure the selection of the most efficient in body from among those who are nearly on a par intellectually.

Mr. Galton also read a paper on the principle and methods of assigning marks for bodily efficiency. Two separate considerations are involved in the just determination of a scale of marks, which are usually mixed up in unknown proportions. (I) Absolute performance-on the principle that if the daily output of one man is greater than that of another, he should be more highly paid, or marked, in that proportion. (2) Relative rankon the principle that superiority, however small, insures success 
in competitions, and therefore the order of merit deserves recognition independently of the absolute amount of performance. The general conclusion is, that before proceeding to decide on scales of marks numerous measures should be discussed, made of persons of the same age and social class as the candiclates, so that the quality of the men hereafter to be dealt with shall be statistically determined. The next step is to decide upon the relative weights to be allowed for absolute performance and for relative rank. Then, after a few other obvious preliminaries have been settled arbitrarily, consistent scales of marks could be at once drawn up.

A paper on left-leggedness, by Mr. W. K. Sibley, was read, in which the author contended that man is either naturally or artificially right-handed and left-legged, and, in walking, tends unconsciously to bear to the right; while the lower animals, on the other hand, appear nearly always to circle to the left. The left foot is more frequently the larger in the male than in the female sex, and the percentage of feet of the same size is greater in the female. The percentage of the right larger than the left is very constant, whereas the numbers of the left larger and those in which both feet are the same size are much more variable.

Prof. D. J. Cunningham read a paper on the occasional eighth true rib in man, and its possible relationship to righthandedness. In seventy subjects examined the anomaly occurred fourteen times, i.e. in 20 per cent. It was found twice in the male for every once in the female. Five cases were bilateral, nine cases were unilateral, and of these no less than eight exhibited the anomaly on the right side. From this Prof. Cunningham considered that it was just possible that the anomaly might have some connection with right-handedness.

The following papers were also read:-Dr. W. Wilberforce Smith, on the early failure of pairs of grinding teeth ; Dr. Ridolfo Livi, on the development of the wisdom teeth; Prof. D. J. Cunningham, on the proportion of bone and cartilage in the lumbar section of the vertebral column in the apes and in different races of men. Prof. Cunningham also exhibited the model of the head of a man stated to be 106 years old, with the brain exposed, in situ; and the model of the head and shoulders of a young orang-utan, with the brain exposed, in situ.

On Friday, September 13, His Excellency Governor Moloney, C.M.G., read a paper on African airs and musical instruments. He distributed the airs geographically as follows :-A, Gambia B, Ewe or Dahomey; C, Yoruba; and D, Houssa. In the first division specimens were given of Bambara, Manaingo, and Volof melodies, while Popo and Dahomey airs illustrated section B. The Yoruba division included Lagos, Ibadan, and other airs, and reference was made to several Houssa melodies. These countries were topographically described, and brief reference was made to their musical instruments and to the native minstrels. The paper concluded with an explanation of what is known as the "drum language."

Mr. Paul B. Du Chaillu read the next paper-the Vikings the direct ancestors of the English-speaking nations. The author described the early civilization and antiquities of the North-men, and dwelt upon the beauty of their ornaments and weapons, and also upon the similarity of Scandinavian and English ornaments belonging to the Early Iron Age, and the love of the Northern people for the sea. He spoke of the three maritime tribes of the North, according to the Romans, and of the fleets of the Sueones in the time of Tacitus; of the expeditions of the so-called Saxons and Franks, and of the home of these tribes; of the proofs from antiquities found in the North of the commerce of the North-men with the Roman Empire and with Greece ; and also pointed out that the tribes of Germania were not a seafaring people, and were uncivilized, according to Roman writers. He gave an account of the probable origin of the names "Saxon" and "Frank," and spoke of the early settlements in Britain by the North-men during the Roman occupation, and of how the name of England might have been given to part of Britain. He alluded to the different countries of the Jutes, and how the language of the North and that of England was similar in early times, and that England was always called by the North-men one of the Northern lands. He mentioned the English and Frankish chronicles, in which the Sueones, Danes, and North-men are described, and that neither Saxons or Franks were a sea-faring people either at the time of Charlemagne or at any earlier period, and he dwelt on the mythical settlement of Britain by Hengist and Horsa, given by the English chronicles, which is quite contrary to the Roman records, Sagas, and archæology, and concluded by expressing his belief that the North-men, or Vikings, were the direct ancestors of the English people.

Canon Isaac Taylor contributed further researches as to the origin of the Aryans. Since the Manchester meeting of the Association in 1887 , when the author read a paper on the same subject, he had re-examined the whole question from the anthropological rather than from the philological point of view. Assuming that there had been no migration of any new race into Europe since the Neolithic period, he contended that anthropologists have established the existence in Europe of four distinct prehistoric races, which might be reasonably connected with four existing types, which occupied nearly the same regions as the four prehistoric races. We have (I) the tall northern dolichocephalic race, the Canstadt race of De Quatrefages, which is the Scandinavian race of Penka, and the Eguisheim race of other writers. The stature of this race amounted to 5 feet ro inches. It was platycnemic, prognathous, and dolichocephalic, with a mean cephalic index of from 72 to 73 . The only pure descendants of this race are the North Germans and the Swedes. This Scandinavian or North-German type is maintained by Penka and other German writers to represent the primitive Aryans, who conquered the other European races and imposed on them their own Aryan speech. (2) We have a second type, also dolichocephalic, called the Silurian type by Prof. Rolleston, which is found in the long barrows of England. The normal stature was short, averaging 5 feet 4 inches; 6 inches less than that of the other dolichocephalic race. The cephalic index is between 73 and 74 . This race was orthognathous, and swarthy, with dark curly hair, oval face, and feeble muscular development. It is now represented by the Welsh of Denbighshire, by the Irish of Kerry and Galway, by some of the Scotch clans, by the Spanish Basques, the Corsicans, the Sicilians, the Berbers, and the Guanches of the Canary Islands. (3) We have a tall northern brachycephalic race, represented in the round barrows of the Bronze Age in England, in the tumuli of Denmark and some caves of Belgium. The average stature was 5 feet $8 \frac{1}{2}$ inches, the mean cephalic index was $8 \mathrm{r}$. It was macrognathous-with projecting teeth and powerful jaws, a square powerful chin, and a face quadrangular rather than oval. It is almost certain that the hair was light, either red or reddish. yellow. It was, in all probability, the race which introduced Celtic speech into England, and is now represented by the tall, yellow, freckled Irish, by some Highlanders, by the Danes, and most of the Slaves, by the Esthonians, and by many FinnoUgric tribes. (4) The fourth prehistoric race was also brachycephalic, but short in stature. It never penetrated to England, but is represented in the sepulchral caves of the Lesse in Belgium. The stature was from 5 feet to 5 feet 3 inches; the mean cephali index was 84 ; it was orthognathous and acrocephalic. It is now represented by the short dark population of Central France, more especially by the Auvergnats, the Savoyards, and the French Basques. It is found in the Rhætian Alps and among the Lapps. The hair is black and straight, and the eyes are dark. These four types and no others appear to have occupied Europe in the Neolithic period. It is difficult to find for them unexceptionable names, but we may for convenience call the first the Scandinavian type, the second the Silurian type, the third the Slavic type, the fourth the Auvergnat type. We have to determine which of these four races was probably the original Aryan race. The primitive Aryans must have either been by race Scandinavians or Slavo-Celts, and one must have imposed Aryan speech on the other. The Celts seem to have been in a higher stage of culture than the Germans, and therefore it is more probable that the Celtic race Aryanized the Teutonic race than that the Teutonic race Aryanized the Celtic race. Two hypotheses are possible-either the human race originated in Europe, bifurcating into the African and Asiatic races ; or we may suppose the white or European race to have originated from the union of the yellow race of Asia and the black race of Africa.

Canon Taylor also read a paper on the ethnological significance of the beech. While the Latin fagus and the Gothic botea denote the beech, the word has come to mean the oak in Greek. The author endeavoured to show that the word fagus originally denoted the beech and not the oak, also that the Greeks entered Hellas from the north-west. The range of the beech is limited. It is a lover of chalk soils, and does not grow east of a line drawn from Königsberg to the Crimea. West of this line we must therefore put the cradle of 
Latin, Greek, Celtic, and Teutonic peoples, as they had the same name for the tree prior to their linguistic separation. The Lithuanian and Slavonic tongues must have originated east of this line, as their name of the beech is a loan-word from the German. The early home of the beech seems to have been limited to France, Central and Southern Germany, Northern Greece, and Northern Italy. If, as has been contended, the cradle of the European Aryans was in Central Asia, where the beech is unknown, it is difficult to explain how the ancestors of Celts, Latins, Greeks, and Teutons migrating, at different times and by separate routes, to lands where the beech abounds, should have called it by the same name, modified in each case by the fundamental phonetic laws of the various languages. It is easier to believe that the cradle of the Aryans was, so to speak, astride of the beech line, the ancestors of Celts, Latins, Greeks, and Germans living to the west of it, and those of the Lithuanians and Slaves further to the east.

In a paper by Mr. Hyde Clarke, on the right of property in trees on another's land, as an origin of rights of property, the author stated that his attention was first called to the subject, as a Land-judge or Commissioner in Asia Minor, in 1862, in granting compensation for olive-trees belonging to one or more individuals on the fields of others, and for honey-trees or hoards of wild honey in State or Communal forests. The author had found evidence as to the existence of the custom in Borneo, with regard to Tapang or honey-trees, and in Chota Nagpore as to the Mhowa, a tree furnishing food, spirit, oil, \&c. In China a lessee has the right to bamboo, \&c., grown by him. The practice in the Turkish Empire he found extended into the European provinces, as applied to plum-trees in Bosnia. In Ireland it was recognized in the Brehon Laws as an individual property separate from tribal property. It is probable that the personal right of the first discoverer of honey and similar trees is to be regarded as the origin of an individual right of property rather than any right in land, which is of no value in a primitive community. Even cultivable land belonged to the community, and was distributed by lot yearly.

A paper by the Rev. J. Wilson, on an hypothesis of a European origin of early Egyptian art, was also read.

On Monday, September 16, Dr. Garson exhibited an anthropometric instrument specially designed for the use of travellers. This instrument occupies very little space, and its weight is scarcely more than that of a detective camera. It can be used for taking all measurements of length and diameter with ease and accuracy.

Mr. Francis Galton, F.R.S., exhibited an instrument for measuring the reaction time to sight and sound signals, and ex plained that they heard much about the quickness of hand and eye. When anyone saw or heard a thing he made a movement, and between the sight and the movement many physiological processes took place so quickly that the flash of lightning was nothing to it. The instrument he exhibited was intended to make an accurate measurement of the time which elapsed between the seeing or hearing of anything and the time occupied in making a certain movement afterwards.

Dr. Thomas Wilson gave an account of the Smithsonian Institution in the United States of America, and its work relating to anthropology.

In a paper by Dr. MacLaurin, on the British race in Australia, the author said that he did not think there was any distinct type of configuration in the Australian-born inhabitant which was sufficient to distinguish him from the ordinary Englishman, Scotchman, or Irishman. The muscular vigour of the British Australian race could be estimated by the readiness with which it entered into athletic exercises, and the result of this had been evident in the number of sculling champions and cricket teams that had recently visited this country. The population was in creasing through the excess of births over deaths, which showed that the vitality of the race had not been diminished by transplantation to Australia.

Mr. H. H. Risley next read a paper on the study of ethnology in India. It was shown that the population of Northern India comprised three distinct types, viz. :-(I) A leptorline dolichocephalic type of tall stature, fair complexion, and high facial angle, apparently corresponding in all points, except hair and complexion, with the Aryan type as defined by Herr Karl Penka, of Vienna. (2) A platyrhine dolichocephalic type of low stature, black or very dark complexion, and low facial angle. The wider racial affinities of this type are uncertain, and it is tentatively and conjecturally described as Australioid. (3) A mesorhine, platyopic, brachycephalic type of low stature, yellowish complexion, and low facial angle, described, in virtue of its low naso-malar index, as Mongoloid. The types thus worked out by anthropometric methods were shown to correspond with certain ethnographic groupings independently ascertained. In the A.ryan and Australioid types the social status of each caste or tribe is found to vary inversely as its nasal index; tribes with the highest index having the lowest social rank, and vice vers $\hat{a}$. In the brachycephalic group social status appears to vary with the cephalic index. An attempt was made to deduce a theory of the probable origin of caste, and also to account for the custom. of exogamy by the operation of the law of natural selection.

Prof. A. C. Haddon read a paper on some former customs and beliefs of the Torres Straits islanders. The natives of Torres Straits are divided into two distinct tribes--the eastern tribe, which inhabits Uga, Erub, and the Murray Islands; and the western tribe, which occupies all the remaining islands. The islanders were divided into clans, each clan having some animal for its totem, such as the dugong, turtle, dog, cassowary, snake, shark, \&c. The women used to have a representation of their totem cut on the small of the back. In the western tribe the lads on entering into manhood underwent a month's isolation in the bush. In the eastern tribe two elaborate ceremonies at tended the initiation of the lads, but the discipline does not appear to have been so severe as in the other tribe. It was the custom in the western tribe for the women to ask the men in marriage. On the other hand, in the eastern tribe the men proposed to the women, and the women had to undergo a period of partial seclusion previous to marriage. The eating of food together was a feature in marriage. Belief in sorcery was universal, and all sickness and death were attributer to the charms of the medicine-man. There were also rain and wind makers.

Some observations on the natural colour of the skin in certain Oriental races, by Dr. J. Beddoe, F. R.S., was read. The author made numerous observations of this kind in the course of a voyage round the world. In most cases he found the colour of the clothed and protected body much lighter than is generally supposed. The capacity to tan, or become darker by exposure, varies much thus the Melanesians are naturally lighter than the Australians, but they burn much blacker.

The following papers were contributed by Dr. R. W. Felkin: the normal temperature of the Soudanese, Negroes, and Europeans in Tropical Africa ; and the differences of sensibility between Europeans and Negroes, and the effect of education in increasing the sensibility of Negroes. Some anthropological notes collected by Mr. Edward Beardmore at Mowat, Daudai, New Guinea, were also read.

On Tuesday, September 17, Dr. Fridtiof Nansen read a paper on the Esquimaux. He said they were a race by themselves, and he did not think anthropologists agreed yet as to their real origin. He thought that tradition showed the Esquimaux really carne from America. The Esquimaux of Greenland were now divided into two classes-those on the west coast who had been civilized by the Danes, and those on the east coast who were uncivilized. Esquimaux were seen in the north in 1823 . The eastern Esquimaux had warmer clothes than the western ones. The young girls wore their hair loose, but afterwards they put it up in a knot at the top of the head, as a sign that they were ready for marriage. The Esquimaux, as a rule, lived in small tribes, and as many as ten families often lived in one hut. The Esquimaux had no written laws, but they had unwritten laws, which were kept strictly. The head of the house and the chief of the tribe was the best catcher of seals. As to property, they did not really know that word. No man had anything for himself, and any seals caught were divided between the families. They did not steal from each other, but they liked to steal from Europeans. Murder was not uncommon amongst the Esquimaux, and the punishment was really nothing at all. The men married as soon as they could catch sufficient seals to provide for a wife. Near relations, such as cousins, never married. On the east coast some men had two wives, the reason being that one wife could not prepare all the seals they caught. The children were not punished. Weak and deformed children, and those who Iost their mothers, were as a rule thrown outside the house or into the sea. Old people, who were ill, were often thrown into the sea. He thought the time would come when the Esquimaux would be extinct.

The Rev. G. Rome Hall read a paper on Northumberland in prehistoric times. On the east coast of England no trace of the Cave-men had as yet been found further north than Norfolk. 
We came, after an immense and unknown lapse of time, to the Neolithic period, when the earliest inhabitants of Northumberland, who were, so far as can be ascertained, cognate with the Basques and Lapps, crossed the Tyne in small family or tribal bands. Though probably never numerous, their polished weapons and implements had been frequently found. Considerable hoards of bronze had been found near Alnwick, Rothbury, and Wallington. Beads of gold were discoveres in a barrow at Four Laws, or Chesterhope. Near Bellingham, in North Tynedale, a gold armlet was found. Burial by inhumation was customary in the later Stone Age, and cremation followed. Interments were sometimes in split oak coffins, found at Featherstone, but usually in stone-lined graves, the body being doubled up as in the posture of sleep, sometimes with an iron food-vessel placed near the head. The author explained the migrations of the people in early times. To the Iron period we owed the introduction of the greater part of the names of local mountains, hills, rivers, and streams, as the Tyne from "don" or " tan," the water. The bronze-using invaders may have landed in England about B.C. IOoo, and the Iron Ige in Northumberland might have begun about B.C. 500 or 400 . Modern Northumbrians, be concluded by remarking, might perchance owe more than they thought to the combination of racial characteristics resulting from the continuity of life proceeding from even prehistoric times down to the present day.

Sir William Turner read a paper on implements of stags' horn associated with whales' skeletons found in the Carse lands of Stirling. He showed that skeletons of whales had been found, together with implements of stags' horn. The discovery of these horn implements showed that when the fertile land now forming the Carse of Stirling was submerged below the sealevel, the surrounding high lands were inhabited by a hardy Caledonian race, who manufactured useful tools and weapons from the antlers of the red deer. It was probable that the whales had been stranded during the ebb of the tide, and that the people had descended from the adjacent heights, and, with the aid of their chisels of horn, had spoiled the carcass of its load of flesh and blubber. There was nothing in the shape of those implements to lead anyone to suppose that they could be used in the chase of the whale. The period of this people was probably covered by that termed the Neolithic, the termination of which was stated to be from 5000 to 7000 years ago.

Mr. Bernard Hollander read a communication on the relations between brain-functions and human character, with the view of showing the possibility of a scientific phrenology.

The following papers were also read :-Prof. G. J. Romanes, F.R.S., on the origin of human faculty ; Prof. Frazer, on a new method of illustrating the topographical anatomy of the brain $\mathrm{Mr}$. George Weddell, notes on classification in sociology ; Mr. S. B. J. Skertchly, on fire-making in North Borneo, and on some Borneo traps ; Mr. James Macdonald, on manners, customs, and superstitions of South African tribes.

\section{THE MAORIS.}

$A \mathrm{~N}$ unusually lengthy Report from the Registrar-General of A New Zealand on the condition of that colony, which has lately been laid before Parliament, contains some interesting information respecting the present condition of the Maoris. Mr. Brown says that, according to the traditions of the Maoris, their ancestors first arrived in New Zealand from an island in the Pacific Ocean, to which the name of Hawaiki is given. Since that event it appears, from genealogical sticks kept by the tohungas, or priests, that about 20 generations of the race have lived. The number of the Maori race at the time of the first foundation of the colony, in I \&40, was estimated at about 80,000 . Twenty years previously the number had been estimated at 100,000. In 1857 an enumeration of the race was made, from which it appeared that the number of males was then about 31,667 , and that of the females about 24,303 ; and of those whose sex was not stated, 79 ; a total of 56,049 . Subsequent attempts at enumeration have been made; but, owing to the objections felt by natives to stating their numbers, and to the difficulties experienced in obtaining information in those parts to which the European was not allowed free access, with not wholly satisfactory results. The latest, and probably most accurate, of these enumerations, was made in 1886 . This gave the number of males as 22,840, and the females as 19,129 ; a total of $4 \mathrm{r}, 969$.

That there has been a serious decrease in the numbers of the race of late years is the general opinion of all competent to judge, and a consideration of the numbers of each sex, and the proportion living at each age-period, leads to the conclusion that in all probability the decrease is still progressive. In I 886 the proportion of females was 83.75 to every 100 males. In the European portion of the population the proportion was $85^{\circ} 28$ females to 100 males. The proportions are not relatively comparable, as the excess of European males over females is caused by immigration; but there is no external cause to account for the Maori males being more numerous than the females. In the European portion of the population, under 20 years of age, the proportion was 100 males to 99 females; in the Maori population under 20 , the proportion was 100 males to 87 females. The males under 15 years of age were in the proportion of 31.82 to every 100 of the male population, and the similar proportion among the females was 33.59 ; these being less than the proportions in $188 \mathrm{I}$ - an evidence of a low birthrate, or high juvenile mortality, leading to a racial decrease.

On comparing the proportions living at each quinquennium uuder 20 , and each decennium above that period, with the corresponding proportions in the population of England, and that of the New Zealand European, it is found that at all ages under 20 the proportions among the Maoris are far less than among the other two populations, and at each age-period above 40 the Maori proportions are far higher. It is, of course, a fair inference that the causes of these larger proportions at the higher age-periods are two-fold-namely, a low birth-rate, and a high death-rate among the younger members of the community. This is borne out by the much smaller proportions of young children to those in either the English or New Zealand European communities. The smaller proportion of females $(83.75)$ to males (IOO) also shows a greater mortality among the adult females than among the males, as 42.29 per cent. of the females living were runder 20 years of age, but only $39^{\circ} 70$ per cent. of the males were under 20 . The manifest decrease in the numbers of the race is much to be regretted, for the Maoris show great aptitude for civilization, and they possess fine characteristics, both mental and physical, and rapidly adopt the manners and customs of their civilized neighbours. In mental qualifications they can hardly be deemed as naturally an inferior race, and the native members of both the Legislative Council and the House of Representatives take a dignified, active, and intelligent part in the debates, especially in those having any reference to Maori interests. The Maoris contribute largely to the taxation of the country through the Customs duties; and, having regard to the relations now subsisting between the races, they may be regarded as constituting an important element of strength in the population of the colony.

On the subject of the education of the natives, Mr. Brown says the number of native village schools at the end of 1887 , either supported or subsidized by the Government, was seventynine, an increase of eight on the number in 1886. In addition, there were two more subsidized private schools for the education of Maori children only, and seven boarding-schools for native children, the cost of whose maintenance was paid either by Government or out of endowments. The number of Maori children attending school at the end of 1887 was 2812 , viz. 1612 males and $\mathrm{r} 200$ females. These included children of mixed European and Maori blood, who live as members of native tribes. The following is a statement of the number of Maori children who were attending schools in 1886 and 1887 :-

\begin{tabular}{|c|c|c|}
\hline At public European schools $\quad \ldots \quad \ldots$ & 475 & $\ldots$ \\
\hline $\begin{array}{l}\text { village schools ... ......... } \\
\text { dized or endowed boarding- }\end{array}$ & 1910 & $\cdots$ \\
\hline $\begin{array}{llll} & \\
\text { ols } \quad \ldots & \ldots & \ldots & \ldots\end{array}$ & $\begin{array}{l}162 \\
100\end{array}$ & \\
\hline
\end{tabular}

There was thus an increase of 165 on the number of native children who were being educated in 1887. There was a decrease of 132 in the number attending European public schools, but an increase of 305 on the number attending the native village schools.

The information supplied respecting the age of the Maoris at the census of 1881 was very incomplete, and therefore only a merely approximate estimate can be given as to the numbers living at the usual school ages, 5 to 15. Out of a Maori population of 22,840 males and 19,129 females, the ages of 21,724 males and 17,936 females were given as either under or over 15 years. The proportion of those under 15 , if applied to the whole of the population, would give 7226 males, and 6420 